\title{
Reorganization of industrial zones as a factor of sustainable development of urban areas
}

\author{
Inna Baranova ${ }^{1}$, Maria Vlasenko ${ }^{1,2, *}$, Tamara Dzholdosheva ${ }^{3}$, and Eugenia Prikhodko ${ }^{1,4}$ \\ ${ }^{1}$ Novosibirsk State Technical University, 20 K. Marx Ave., 630073 Novosibirsk, Russia \\ ${ }^{2}$ Novosibirsk State University of Economics and Management, 56 Kamenskaya str., 630099 \\ Novosibirsk, Russia \\ ${ }^{3}$ Kyrgyz Economic University named after M. Ryskulbekov, Bishkek, Kyrgyzstan \\ ${ }^{4}$ Altai State University, Pr. Lenina, 61, 656049 Barnaul, Russia
}

\begin{abstract}
The reuse of industrial zones is becoming one of the determinants of sustainable urban development, which ensures the effective use of urban areas, taking into account the principle of their integrated development. However, the modern urbanized environment has serious environmental problems, which limits the active use of the redevelopment tool. The conducted research of the implemented redevelopment projects showed that their main share is accounted for the construction of apartments and housing, multinational complexes, creative spaces and offices. The results of the cluster analysis of the territories of Russia allowed the authors to identify the most promising regions for redevelopment.
\end{abstract}

\section{Introduction}

The vast territories of industrial zones, a legacy of the post-industrial era, are now surrounded by a rapidly expanding urban space. The modern urbanized environment concentrates serious environmental problems associated with air pollution, reduction and degradation of green spaces, overgrown industrial zones, which actualizes the need to restore a favorable living environment, starting with the identification of the most neglected areas and their ecological reconstruction. Reconstruction, modernization, redevelopment, redevelopment - this is not a complete list of options for the reorganization of industrial zones, which allow for the effective use of urban areas, ensuring their sustainable development. Reconstruction of individual real estate objects in order to use them more effectively is a process of redevelopment, which is aimed at changing existing buildings, including industrial zones, and allows you to get financial, social and environmental effects. The process of redevelopment in the last 40-50 years has become widespread all over the world, when industrial enterprises began to move production to the outskirts of cities in order to effectively operate and improve the environment in urban centers. In the end, the redevelopment of urban areas allowed many cities to form micro districts with developed infrastructure, significantly improving the quality of life of people.

${ }^{*}$ Corresponding author: vma-1991@yandex.ru 


\section{Materials and methods}

A set of theoretical research methods, analysis of foreign and domestic practices of redevelopment of industrial zones and territories; cluster analysis of Russian territories.

\section{Results and discussion}

\subsection{Redevelopment of industrial zones as a factor of sustainable urban development}

The re-use of industrial zones is now becoming the most important issue of sustainable urban development; a large number of publications and studies are devoted to this problem. Canevaro E., Ingaramo R., Lami I.M., Morena M., Robiglio M., Saponaro S., Sezenna E. [1] note that the rapid deindustrialization of Western economies has had a huge impact on the urban landscape in Europe, leaving industrial zones on the territory of cities [1]. The re-use of industrial zones is based on the maximum safety of the created assets, minimizing time, materials, invested energy costs and preserving the identity of the object. Since modern urban planning lags behind urban development due to the rapid growth of the urban population, according to Zhou G., Li C., Li, M., Zhang J., Liu, Y. [2], the growth of urban space can occur not only through the expansion of urban land, but also through their transformation based on redevelopment. At the same time, it is necessary to take into account the conversion characteristics of industrial zones and use them for the development and reconstruction of cities. For example, De Giovanni G., Scalisi F., Sposito C. [3] note that most of the major cities in Italy have abandoned industrial zones, which actualizes the problem of rethinking and reusing them for the purpose of urban sprawl. Niemets L., Husieva N., Suptelo O., Sehida K., Kravchenko K. [4] state that in many cities of various countries of the world, "gray zones" have formed, represented by old buildings for various purposes (primarily industrial), which, as a result of changes in market conditions, have become unnecessary, have ceased to exist or are not working at full capacity. Such territories cause a number of problems in the functioning of urban spaces, associated with a negative impact on the environment, violation of the proportions of urban planning, the production of hypertrophied traffic flows, provoking social tension, low economic efficiency, etc. In this regard, there is a need for further use of "gray areas" in urban economic activity to revitalize the surrounding urban space. The main strategies for their development are the conversion strategy and full refunctionalization.

Cheirchanteri G. [5], studying the industrialization of the Grotii, emphasizes that it began in port cities that have an industrial character of the coastal zone. By the end of the 20th century, factories representing heavy industry in the areas west of the port of Piraeus began to close due to environmental pollution. As a result, the coastal region, which was previously an industrial area, became industrially inactive, a number of industrial buildings were demolished, and others faced the task of modernization with the guarantee of preserving the high quality of the environment and infrastructure [5].

Schaefer W. F. [6] also links the steady economic growth of cities to the redevelopment of old industrial zones, noting that the average time required for their reconstruction in the Netherlands is 10 years; about $30 \%$ of Dutch industrial zones are outdated, which requires their redevelopment, including using the experience of Lisbon.

Lee I., Hwang S. W. [7] emphasize the decline of the manufacturing industry in cities as a global phenomenon that leaves behind abandoned industrial zones. The presence of abandoned and unused industrial zones encourages many cities to implement various reconstruction strategies [7]. Asian cities, experiencing similar changes in industry and urban landscape, in order to revitalize abandoned industrial areas and focus on the population, 
choose the construction of multi-purpose commercial complexes that combine culture and entertainment as a redevelopment strategy. The researchers note that as a result of the reconstruction of large post-industrial sites in Seoul, sustainable urban infrastructure, improved urban environment and design quality were provided.

Thus, as foreign practice shows, redevelopment, focused on the formation of a comfortable and modern living environment, becomes an instrument of integrated and sustainable development of urban areas.

\subsection{Risks of reuse of industrial zones}

Canevaro E., Ingaramo R., Lami I.M., Morena M., Robiglio M., Saponaro S., Sezenna E. [1] note that "the problem of environmental pollution is often the main constraint for urban redevelopment" and the redevelopment of industrial zones. Wu Q., Zhang X., Liu C., Chen Z. [8] state that after decades of urbanization and economic boom, China has entered a phase of economic restructuring of its cities. But the process of redevelopment and reuse of industrial zones is accompanied by certain risks: chemical and heavy production are the main industries in most of the industrialized cities of China, so the health of the population and the environment are at risk due to the risk of soil toxicity, as reurbanization and redevelopment involve the creation of new residential and public areas on the territory of old industrial areas.

The presence of a risk to human health when using abandoned industrial zones is noted by Wcislo E., Bronder J., Bubak A., Rodriguez-Valdes E., Gallego J. L. R. [9]. By saying that abandoned industrial zones can have the potential for re-development and create conditions for urban development, bringing social, economic and environmental benefits from re-use, the authors emphasize the problem of soil pollution in Europe, which is a factor of adverse effects on human health.

To assess the environmental risks in the territories of former industrial zones, geological and environmental studies are carried out, including environmental expertise, after which decisions are made on how to prepare the territory for construction; at the same time, the reclamation of the territory of industrial zones is necessarily carried out.

\subsection{Structure of redevelopment projects}

The study revealed that redevelopment projects are being actively implemented in different countries of the world; abandoned railway stations, factories, warehouses and factories are being transformed into modern hotels, loft parks, business and shopping centers (Fig. 1). The main part of redevelopment projects is represented by the construction of apartments and housing, multinational complexes, creative spaces and offices.

A significant share of redevelopment projects is in Russia: almost $92 \%$ of potential projects and $33 \%$ of completed projects. This fact is explained by the large area of the territory of Russia and industrial zones, as a legacy of the era of industrialization. It should be noted that redevelopment projects are being actively implemented in the UK, Germany, the USA and other countries. 


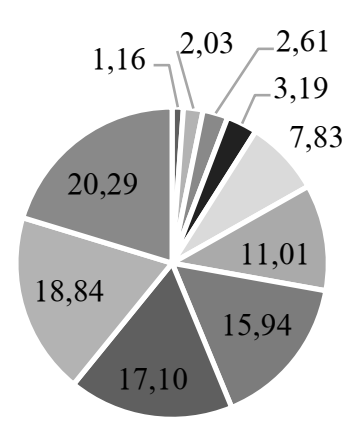

- Warehouses/production

- General category

- Restaurants

- Shopping and entertainment centers

- Hotels

- Social facilities

- Offices

- Creative space

- Multifunctional complexes

- Apartments/ housing

Fig. 1. Structure of implemented development projects, $\%$ Compiled by the authors of [10]

The distribution of redevelopment projects, taking into account the stage of their implementation, is shown in the fig. 2.

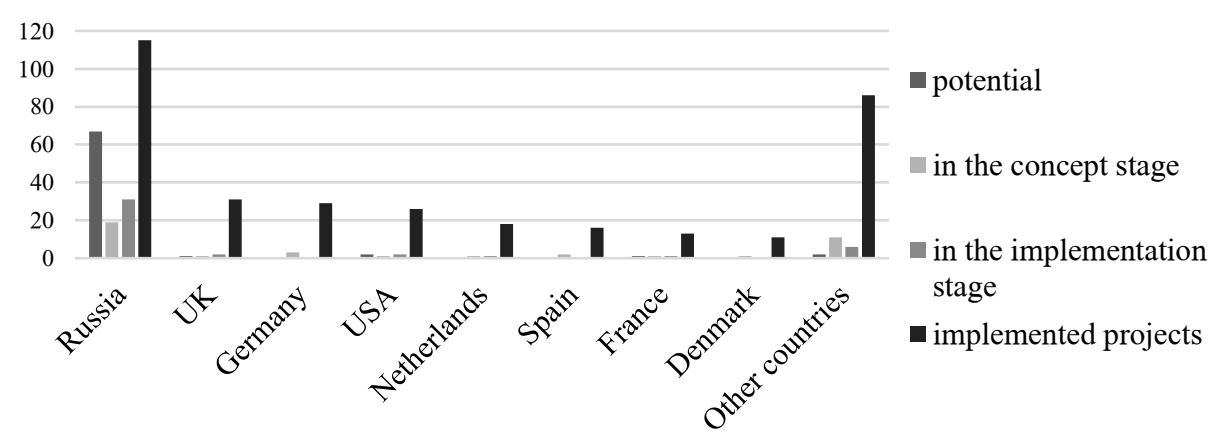

Fig. 2. Development projects, taking into account the stage of their implementation in a number of countries

Compiled by the authors of [10].

Turning abandoned industrial zones into effectively used territories, redevelopment solves the following tasks: creating new jobs, restoring and developing the housing and communal and production sectors of the economy, the social security system of the population and services, which ultimately ensures sustainable development and the formation of a favorable

\subsection{Ranking of the territories of the Russian Federation according to the expected socio-economic effects of redevelopmenturban environment for the population.}

Reducing the impact of territorial and socio-economic inequality resulting from the implementation of the eleventh UN Sustainable Development Goal forces us to look for new sources of improving the standard and quality of life of the population.

However, according to the Country Rankings by Country of Price per Square Meter, published on the Numbeo resource [11], which reflects the average cost of one square meter of urban housing in the city center (measured in US dollars), for 2017-2020. (the last rating change is mid - 2020) in a number of countries, prices have more than tripled: Hong Kong (1st place in the rating) has doubled, Singapore (2nd place in the rating)-2.1 times, South 
Korea (3rd place in the rating)-3.5 times, Russia (82nd place in the rating) - 2.5\%. The Knight Frank's Global House Price Index, covering more than 55 countries, revealed an average increase in urban real estate prices by $5.6 \%$ in the 4th quarter of 2020 (5.3\% in 2019); an increase in prices in the Russian Federation - by 14\% [12].

Russia ranks first in the ranking of European countries in terms of the number of apartments built in 2017-2019 per 10 thousand people, however, the Russian Federation is at the end of the country's rating in terms of the population's availability of living space [13].

The solution to the problem of sustainable development in terms of ensuring access to sufficient, safe and affordable housing is limited, on the one hand, by the availability of free space for development within cities, on the other, by the cost of construction and maintenance of expensive communications. Redevelopment of inefficient industrial zones should become a source of sustainable development of urban areas.

To determine the most promising areas for redevelopment, we analyzed the federal districts of Russia according to three independent statistical indicators: the annual volume of housing commissioning; the number of residential apartments commissioned per 1000 people of the population and the total area of residential premises accounted for on average per inhabitant of cities and urban settlements. Table 1 shows the results of the ranking of federal districts, starting from 2018.

Table 1. The rank of the federal districts of Russia in terms of housing commissioning and provision of the population with it

\begin{tabular}{|c|c|c|c|c|c|c|c|c|}
\hline \multirow[t]{2}{*}{ Federal District } & \multicolumn{3}{|c|}{$\begin{array}{l}\text { Housing commissioned, million } \\
\mathrm{m}^{2}\end{array}$} & \multicolumn{3}{|c|}{$\begin{array}{l}\text { Number of apartments } \\
\text { commissioned per } 1000 \text { people } \\
\text { (unit, indicator value per year) }\end{array}$} & \multicolumn{2}{|c|}{$\begin{array}{c}\text { Total area of } \\
\text { residential premises, } \\
\text { on average per one } \\
\text { inhabitant (m2, value } \\
\text { of the indicator per } \\
\text { year) }\end{array}$} \\
\hline & 2018 & 2019 & 2020 & 2018 & 2019 & 2020 & 2018 & 2019 \\
\hline Central & 1 & 1 & 1 & 2 & 2 & 3 & 2 & 1 \\
\hline Privolzhsky & 2 & 2 & 2 & 5 & 5 & 5 & 4 & 4 \\
\hline Northwestern & 3 & 4 & 4 & 1 & 1 & 1 & 1 & 2 \\
\hline Southern & 4 & 3 & 3 & 3 & 3 & 2 & 3 & 3 \\
\hline Siberian & 5 & 5 & 5 & 6 & 6 & 6 & 6 & 6 \\
\hline Urals & 6 & 6 & 6 & 4 & 4 & 4 & 5 & 5 \\
\hline North Caucasian & 7 & 7 & 7 & 8 & 8 & 8 & 8 & 8 \\
\hline Far Eastern & 8 & 8 & 8 & 7 & 7 & 7 & 7 & 7 \\
\hline
\end{tabular}

Compiled by the authors according to [14]

Based on the experience of other countries, as well as on the results of the authors ' research, it can be expected that the greatest return on redevelopment will be in the cities of the federal districts with the largest rank gap, calculated by the indicators of the total area of residential premises per average resident and the annual volume of housing commissioning. These federal districts include, first of all, the Volga Federal District (the ranking gap in indicators is two), on the territory of which there are 5 out of 15 cities with a population of more than 1 million people. For obvious reasons, the most promising territory for redevelopment is Moscow (2nd place in the ranking of 87 subjects of the Russian Federation in terms of housing commissioning and 83 in terms of the number of $\mathrm{m} 2$ on average per inhabitant).

\section{Conclusions}

As cities develop, they become administrative and business centers, and the need for administrative and office space increases accordingly. Previously dominant industrial zones need to be modernized to ensure the economic development of cities. The master plans for 
urban development provide for the reconstruction of industrial zones, but it is necessary to take into account the environmental risk factors for the reuse of land plots on which industrial zones are located. The complex reconstruction of territories, the creation of multifunctional spaces contribute to the development of urban areas, the formation of a comfortable environment for citizens to live in; at the same time, the redevelopment of urban areas gives a second life (revival) of abandoned factories and other old buildings.

\section{References}

1. E. Canevaro, R. Ingaramo, I. Lami, M. Morena, M. Robiglio, S. Saponaro, E. Sezenna, IOP Conference Series: Earth and Environmental Science, 296 (2019)

2. G .Zhou, C. Li, M. Li, J. Zhang, Y. Liu. View Correspondence Habitat International, 56. (2016).

3. G. De Giovanni, F. Scalisi, C. Sposito. TECHNE, 12 (2016)

4. L. Niemets, N. Husieva, O. Suptelo, K. Sehida, K. Kravchenko. Proceedings of the 32nd International Business Information Management Association Conference (2018)

5. G. Cheirchanteri. World Multidisciplinary Civil Engineering, Architecture, Urban Planning Symposium (2018)

6. International Conference on Sustainable Development and Planning, Sustainable Development III, SUSTAINABLE DEVELOPMENT, 102 (2007)

7. I. Lee, SW. Hwang, SUSTAINABILITY, 10 (2018)

8. E. K. Kuricheva, A. A. Popov. Regional Research of Russia, 1 (2016)

9. E. Wcislo, J. Bronder, A. Bubak, E. Rodriguez-Valdes, JLR. Gallego. Environment International, 94 (2016)

10. ReDeveloper, https://redeveloper.ru

11. Rating of countries by property value, https://nonews.co

12. The Knight Frank: Global House Price Index, https://www.knightfrank.com

13. Rating of European countries for housing construction, https://ria.ru

14. Federal State Statistics Service, https:// https://rosstat.gov.ru 